\title{
Chapter 8 \\ Speaking Truth to Power? Why Civil Society, Beyond Academia, Remains Marginal in EU Migration Policy
}

\author{
Ann Singleton
}

The dynamics of the EU's academic-policy nexus and the EU's attempts to create a common migration policy are documented in the previous chapter and elsewhere in this book. This volume also demonstrates that the nexus is now the subject of a stream of academic writing, as are the outputs on the migration-security nexus (Walters 2010) and the migration-development nexus, in which migrants are increasingly being seen as Transnational Development Agents (Faist 2008). Migration research is something of an industry in its own right, in which examination of these connections illuminates understanding, yet still most non-academics and those in civil society without access to policy-makers remain excluded from the policy discussions. The EU's Global Approach to Migration and Mobility (GAMM) includes some aims to include migrants in a rights-based approach to policy-making (BanulescuBogdan 2011) however this is in a context in which the main EU policy objectives have already been set. (How this happened is described below in Sects. 8.3 and 8.4). The general absence of migrant voices and civil society from the researchpolicy nexus is the result of several factors which have positioned migrants as the object of study and recipients of policy measures. These factors include: the lack of transparency and accountability in EU migration policy-making; the focus of much migration research on policy concerns (currently integration and security); the use of research methodologies which investigate migration-related topics from theoretical and expert, academic positions; the exclusion of migrant voices from media coverage.

Many migrants are excluded from much of society, let alone the migration debates, by citizenship laws, poverty, gendered social and economic injustice and institutional racism. They are structurally excluded and their lives are hidden from the priorities and gaze of the academic-policy nexus (notwithstanding some

\footnotetext{
A. Singleton $(\varangle)$

School for Policy Studies, University of Bristol, Bristol, UK

e-mail: Ann.Singleton@bristol.ac.uk 
excellent qualitative research, social media and 'on the ground' campaigns). Those whose lives are directly affected by migration policy and practice, namely recent migrants, migrant groups, as well as the wider civil society, remain largely marginalised and their voices unheard in the policy discussions. It begs the question, what is academic research on migration for? In the meantime, the focus on integration and security policy appears to dominate the migration research industry. Those outside the nexus, had they the time or inclination to consider it, might wonder what it's all about.

The previous chapter outlines how academic research influenced and became part of the EU policy discussions, particularly regarding demographic change, employment and integration. This chapter argues that these discussions were framed by policy priorities and examines the reasons why there is little meaningful inclusion in policy debates of the views of recent migrants or wider civil society. ${ }^{1}$ It discusses the lack of transparency and accountability in EU and member states' decisionmaking processes and the generally negative media coverage, which informs public opinion and drives much of the content of public discussion.

In order to better inform policy discussions and public debate, it is also essential to understand why some 'truths' about migration become received wisdom and policy priorities, whilst other realities of the lives and deaths of migrants remain largely unheard or ignored. This also raises questions about how much influence it is possible for non-Brussels-based civil society to have on the production of knowledge in the academic and policy domains? It is argued here that the member states and the EU both constrain and enable research in this field.

\subsection{The Relationship Between Research and Policy? The EU, Academia and Civil Society}

Historically, research has been a driver of change in social policy fields, including public health and poverty (Dean 2012: 89). However, in certain fields, including migration, rather than policies being informed by evidence, research is usually commissioned to justify pre-ordained policy decisions: in other words, policy-based

\footnotetext{
${ }^{1}$ The terms 'migrant', 'academic' and 'policymaker' are not mutually exclusive at the individual level, but they describe groups with differing power and influence over migration policy. Recent migrants are those whose lives are most immediately shaped by the effects (intended or not) of the policies. This is being seen to have catastrophic effects for thousands of people who die every year attempting to enter the EU as a result of the prioritisation of border controls and immigration over just migration policies. Civil society is here taken to be organised or collective groups of individuals with common interests, other than state institutions and organisations, the executive (governments), the economy and economic actors. The 'academics' are taken to be those academics who are involved in dialogue with policymakers on migration.
} 
evidence making. Policymakers in the EU, as in many member states, often claim that policymaking is evidence-based. However the evidence that may inform migration policy is a product of a process of knowledge generation that is shaped by the policy priorities themselves. Many individual academics (including the author) and teams of researchers have advised officials and policymakers with various roles on different aspects of migration policy. A number of policy Directorates General (DGs Home, Justice, Employment and Social Affairs) have commissioned research and funded numerous projects on migration and integration, security and the labour market. The policy outcomes generally take little of this work into consideration and policy results 'are often poorly conceived, narrow and contradictory' (Castles 2004: 222). The research parameters in this process are set by officials and usually relate to specified policy objectives. Evidence that does not support policy aims tends not to be considered by the policymakers. Academics facing these constraints tread a delicate path in working on EU and government-funded research projects. At the same time, in the context of economic austerity, it is becoming more difficult to attract national Research Council funding, so funding from government departments and the European Union has become more attractive.

The Commission's Directorate General for Research has also funded, through a succession of Framework Programmes, a wide range of migration-related or -focused research projects (Singleton 2009). The work of these projects has covered several fields including labour market needs, the demographic challenges of Europe's ageing population, the experiences of undocumented migrants, the feminisation of migration, and integration. European Commission officials have often despaired of the lack of 'policy focus' in recommendations from these projects, whilst the migration policy agenda continues to be dominated by security concerns. The academic literature on policy-relevant research agendas has focused on the relationship between policy priorities and research agendas, whilst migrant organisations in civil society have been marginalised throughout the process. There are some good examples of academic research providing resources for wider civil society, for example the Migration Policy Index (MIPEX http://www.mipex.eu/) website, which makes publicly available good quality information on integration policies. This provides material for those engaging in the integration agenda. However, such good examples appear to address, or attempt to influence, mainly the policy parameters of the official work programmes, in this case the integration agenda, with research findings often reflecting the evidence to support or develop established priorities. In general, wider civil society is excluded from the agendasetting role allowed in some instances for academics. Despite strenuous efforts by a number of academics it seems that academic debates often ignore many of the realities of the lives of migrants. Civil society and NGOs are pulled into research projects and legitimate the process, providing empirical evidence, yet not being part of setting the research and policy agenda. A research agenda framed instead in terms of social justice and the social harm effects of policy might encompass a wider field and capture a fuller picture of the rich detail and realities on many migrants' lives. 


\subsection{The Media}

There is a complicated relationship both between the media and policymakers and between the media and the public. The media, another section of wider civil society, play a key role in shaping national public opinion on migration, through information, and misinformation, which is transmitted electronically and in hard copy. This information, including frequent misinterpretation of migration statistics, shapes public perceptions towards migrants and influences the tone and content of public debate. The media also influence government policy with anti-immigrant rhetoric, which in turn is framed by government policy priorities. Negative coverage creates a climate of hostility and fear experienced by those living in migrant communities and stokes a fear of immigration in the whole population across Europe (Canoy et al. 2006). This endangers the chance of rational discussion of what might constitute fair and effective migration policies. In fact, "In most immigration debates, fear resonates much more viscerally than hope" (Papademetriou and Heuser 2009: 4). The stigmatisation of migrants is usually accompanied by a rise in hate crime, whilst in the current economic crisis, migrantled NGOs find it increasingly difficult to obtain funding. Many studies have been carried out at national level into the media coverage on migration (Spigelman 2013; Migration Observatory 2013; Philo et al. 2013). In the UK, its role in transmitting information (and misinformation) on asylum and migration issues has been shown to be unremittingly negative (Philo et al. 2013). This can be seen in the vocabulary of news coverage across all newspapers in which the term 'illegal' is used in predominance to describe 'immigrants' and 'migrants' in general (Migration Observatory 2013).

Some positive stories about individual migrants are published, but reports generally do not include interviews with migrants. In the UK in early 2014, a survey by Migrant Voice of television and press coverage found that migrants were quoted in only $12 \%$ of stories (Migrant Voice 2014). This study found that when stories included interviews with migrants, this added credibility to the reports, however the coverage of migrant groups and communities was found to be generally negative. The picture at EU level reflects that which exists in the member states. As reports cover the crisis and humanitarian disaster of migrants dying in the Mediterranean, the policy framework is poorly explained, if at all. There is little well-informed EU public debate over the causes of the current crises and possible policy options. Those who are rescued from the sea have no say in the policies and practices being juggled between the EU, Frontex and the member states. In addition, most Brusselsbased journalists who have to cover the whole range of EU policies have little time to spend on investigative journalism. On EU migration issues, the media have a generally abysmal record of simply duplicating press releases from the Commission, instead of investigating stories and issues. On the occasions when they do follow up a migration-related story, they have to make a judgement about whether their national editors will give any priority to, or even print, a story on EU migration policy. 
There are some encouraging signs of a will to improve and rebalance the quality and tone of reporting on migration. Migrant Voice (2014) is encouraging journalists to meet a migrant and to reflect more accurately the complexities and realities of the lives of recent migrants. An initiative by the International Federation of Journalists in the form of The Ethical Journalism Initiative (http://ethicaljournalisminitiative. org/), and the global Ethical Journalism Network http://ethicaljournalismnetwork. org/, both offer some hope for improvements in the quality of reporting on migration. Accessing accurate information and being able to inform public debate responsibly remains problematic however, when even well-connected journalists are prevented from having access to the closed meetings of EU officials.

\subsection{Structural Barriers to the Inclusion of Civil Society and Recent Migrants in EU Justice and Home Affairs Policymaking}

The EU policymaking process may take into account evidence from some academic research, but it has not included wider civil society other than in 'consultation'. This section examines how EU policy on migration and asylum has been produced and why input from civil society and migrants has been minimal.

From 1976-1993, the Trevi era, EU cooperation on justice and home affairs issues was intergovernmental. The Maastricht Treaty in 1993 saw many changes that shaped the way in which migration policies would develop, with the setting up of the Justice and Home Affairs Council and the Tampere Summit in 1999.

Between 1976 and 2006, immigration and asylum policy was effectively decided by the Council of Ministers (by the JHA Council after 1993), with measures proposed by the Commission (often following 'informal' discussions about what was possible and desirable between officials in the two institutions). The European Parliament was 'consulted'. After 1993, national parliaments had little power (and rarely exercised that which they had) and civil society was too often a lonely and ignored voice seeking to protect the rights of migrants and refugees. The dangers of the lack of transparency and openness in this process and the implications for democratic decision-making have been well documented by Curtin and Meijers (1997) and Bunyan (2007).

The European Parliament's powers were limited throughout this early period to being consulted on immigration and asylum. Its views were routinely ignored. It was not until 2006 that the Parliament was given the power of co-decision with the Council - and the Council also introduced the practice of first reading trilogues. This is a negotiating process in which the Council and the Parliament discuss and agree a 'compromise' text - and still none of the documents under discussion are officially published, thus excluding civil society from making its views known.

This policy process has throughout been marked by an historical and ongoing reluctance of member states to surrender sovereignty over border controls, whilst 
they cooperate to establish ever tighter external border controls at the physical outer limits of the EU, beyond EU territory and internally. Consequently, the EU reflects and compounds the largely negative stance of the member states towards migration. In fact, much of EU migration policymaking could be described as 'reactive and piecemeal', as has been observed of Greek policymaking (Triandafyllidou 2009). The focus is on the control of immigration, particularly that defined as 'illegal' immigration, rather than on the development of a comprehensive common migration policy. As control of borders is prioritised, Frontex acts as coordinator of the member states' frontline in a war against 'illegal' migration. The consequences include the thousands of deaths each year of people who try to cross the Mediterranean.

\subsection{Why Is It Believed That Civil Society Plays a Role in the Policymaking Process?}

The notion that civil society takes part in the policymaking process is firmly rooted in the dominant academic theory of multi-level governance (MLG), which permeates the disciplines of international relations, European studies and political studies. For many this assumes that 'participation' and 'consultation', as defined by EU institutions, are meaningful in the policymaking process. This may be true to some extent in certain policy areas. However, the involvement of civil society in the migration policymaking process is limited to 'consultation' by the Commission, and only then after a proposal has been drafted (whereas consultation with the member states takes place before proposals are drafted). The Commission then presents its proposal to the Council of Ministers and the European Parliament (EP). Following this, the proposal will be considered in a Council Working Party, chaired by the Council Presidency, with advice from the General Secretariat (which can have a major influence on the content and direction of discussions). At this crucial stage the Council works out its 'position' and civil society has no input. This can take weeks and the documents are usually not made public. Once the 'position' is agreed it goes to COREPER (the Committee of Permanent Representatives of the member states) then to the JHA Council before opening 'trilogues' with the Parliament.

This might be an opportunity for civil society, including recent migrants, to have a say, however the discussions in the trilogues are only recorded by the Council and are not made public. When the Council and EP reach a 'compromise', the text is agreed and the Council Presidency sends a formal letter to the chair of the parliament's Civil Liberties (LIBE) Committee. The text, usually agreed at first reading, then cannot be amended by a 'dot or comma' by the European Parliament in committee or in the plenary. At this stage in the LIBE Committee, $84 \%$ of measures are decided in the first reading trilogues.

It is arguable that civil society has more chance of influencing the European Parliament than the Council or the Commission. However, for any such input to be meaningful, it would be necessary to know the content of the Council discussions and the discussions in the trilogues. 


\subsection{Transparency and Access to Documents}

EU and national officials and the governments of the member states have thus defined the parameters of migration policy and legislation and the terms of debate in this field. The biggest obstacle faced by civil society in attempting to influence migration and asylum policy has been to discover which measures are being proposed. During the years of inter-governmental cooperation, the only voices heard from outside the institutions were those of international organisations such as the UNHCR. As described above, during the inter-governmental phase of EU JHA policies, which established the framework and core basis of JHA common policies, decision-making and policy development took place in the EU institution's committees, principally in the Council of Ministers. This process was largely ignored by the media and did not come to general public attention, meaning that there was no general public discussion of the proposed measures. Many national parliaments remained ill-informed about proposals or had no opportunity to debate them.

Statewatch - an organisation that identified Justice and Home Affairs as a key defining policy area in the emergence of an EU state - has monitored EU activities and the consequences for civil liberties since 1992 (Statewatch 2012). For more than 20 years it has attempted, with some success, to gain access to the documents produced in this policymaking process and to make them publicly available. It has found that lack of transparency and access to documents has resulted in having to devote substantial resources to inform civil society about the development of Justice and Home Affairs policies, including those on migration and asylum. In the absence of 'an EU public access culture' (Bonner 2006: 149), this has been an uphill struggle. The story of this long and continuing attempt to open up information on EU policymaking has been documented elsewhere (Statewatch 2014). Backed by successful complaints from the European Ombudsman, Statewatch has persevered in applications for documents, finding that the path has been blocked by officialdom within the institutions. The EU has been critical of these attempts, claiming at times they are 'vexatious', that the Commission needs the 'space to think' outside public scrutiny and finally, in an Orwellian move, proposing changes to the definition of a 'document', so as to remove the right of access, effectively until measures have been adopted.

There is, in the absence of open access to policy documents, no trilogue or nexus of any meaning or accountability between academics, the rest of civil society and policymakers. When the voices of civil society groups are heard, it is merely through consultation processes, whilst the Commission is drafting the proposal. There is no requirement for policymakers to take any action in response to civil society, whereas there are increasing concerns about the EU's migration activities in general, in particular the externalisation of migration control beyond its geographical and legal borders (Migreurop 2012). Major issues, in addition to the unaccountability of Frontex, are the militarisation of migration control, EU detention camps in nonEU countries, inadequate scrutiny of the implementation of the Returns Program 
and privatisation of many of the activities carried out on behalf of member states, including the detention of children. Migreurop, a coalition of pro-migrant groups across Europe, reports regularly on the consequences of these activities. In addition to the thousands of people who have died trying to enter the EU, EU citizens have been traumatised by witnessing the consequences of Frontex activities in the Mediterranean. These witnesses remain scattered around the seaports of Europe's southern borders. However there is no indication that the member states intend to change current practice. Despite the efforts of Migreurop and others, the general public remains largely ignorant of the policies, the practices, or of their effects. Nothwithstanding the 'noise' around migration policy, those at the sharpest end of policy and practice in the member states are absent from the nexus debates. Asylum seekers in privatised detention centres are not able to meet policy makers or academics and in the UK have resorted to hunger strikes in 2015. In at least one case, in Ireland, politicians have been banned from entering asylum detention centres (The Journal.ie, 22.06.14).

\subsection{Conclusions}

There have been some moves to include civil society organisations in the migration policy field. The work of PICUM is a shining example as is that of the European Network of Migrant Women. The Network of European Foundations has funded the European Programme for Integration and Migration (EPIM). The Hungarian Presidency ran a conference in June 2011, which addressed good practices in reporting migration. Developments in research methodology and knowledge exchange offer new ways to include the voices and direct experiences of those experiencing the effects of policies. In the UK, the Joseph Rowntree Foundation has funded research on the role of NGOs in influencing policy. This research identified the potential of the 'Change from Experience' NGO partnership (Lukes et al. 2009), which employed a critical pedagogy approach to support the effective representation of migrants. The Poverty and Social Exclusion (PSE 2014) project offers a fine example in Northern Ireland of research collaboration between academics and people whose lives are the object of study. This pioneering 'on-the-ground' research has widened community engagement in the research process and collection of qualitative data. The investigation and presentation of research findings has been led by those living with social deprivation and poverty (Kent 2013). Using digital media, the research outputs include films produced by people, adults and children, speaking directly to policy-makers. This model offers an opportunity to include recent migrants in the research process, with the potential to produce and present findings in a form directly accessible to policy makers.

For civil society organisations participating in a liberal democracy, it is essential to have access to information about policy options and to participate in decisionmaking. The absence of this information in this central policy area both calls into question the nature of the EU and raises concerns about the democratic deficit. 
Transparency was presented as the EU's answer to the democratic deficit. The struggle of NGOs, notably Statewatch, for access to documents suggests however that the EU institutions have a long way to go before reaching the stated aim of transparency, let alone full participation of civil society in democratic decisionmaking on immigration policy.

The absence of full participation by civil society in EU policymaking is a matter of concern to all who wish to see evidence-based policymaking in a true sense, as well as democratic decision-making and scrutiny of policy implementation. It cannot be addressed happen without accountability of the EU institutions to the public, particularly those who are subject to the effects of its policies. Where the policies have an impact on non-EU citizens, on or off the territory of the EU, EU citizens must also accept them as legitimate. Without informed public debate on migration, this cannot happen. The EU's border agency, Frontex, epitomises the most negative of EU action on migration, which is least accountable to the citizens of the EU. The agency is characterised by a lack of transparency in its activities, which also reflect the primacy of security over observance of international obligations on the human rights of migrants and asylum seekers. The creation of a consultative committee has not led to independent oversight of Frontex activities.

In summary, there is inadequate scrutiny of the effects of policies or the experiences of migrants within and outside the EU. The media generally fail to investigate the full picture, including the impact of policies. Many or most experiences of migrants within detention and in transit remain hidden from the public. Academic and medical research on the health effects suffered by children and adults in detention has not resulted in the end of such detention.

There are chinks and contradictions in the overall picture. It is possible occasionally to advance and develop policy discussions beyond immediate policy objectives. Arguably, this has happened in relation to the understanding of gender and migration, undocumented migration and integration. Many officials of the EU institutions are well informed on the realities. However, no matter how high the quality of their discussions with academics, or how much innovative research methodologies can bring the voices of migrants to the debate, this better understanding of the issues is unlikely to have significant or measurable impact on the policy priorities of the member states and in the Council of Ministers.

Open Access This chapter is distributed under the terms of the Creative Commons Attribution Noncommercial License, which permits any noncommercial use, distribution, and reproduction in any medium, provided the original author(s) and source are credited.

\section{References}

Banulescu-Bogdan, N. (2011). The role of civil society in EU Migration Policy: Perspectives on the European Union's engagement in its neighbourhood. Migration Policy Institute. www. migrationpolicy.org/pubs/EUcivilsociety.pdf

Bonner, P. (2006). When EU civil society complains. In S. Smismans (Ed.), Civil society and legitimate European governance (pp. 141-168). Cheltenham: Edward Elgar. 
Bunyan, T. (2007). Secret trilogues and the democratic deficit. Statewatch Viewpoint. http://www. statewatch.org/analyses/no-64-secret-trilogues.pdf. Accessed 15 Nov 2013.

Canoy, C., Beutin, R., Horvath, A., Hubert, A., Lerais, F., Smith, F., \& Sochacki, M. (2006). Migration and public perception Bureau of European Policy Advisers (BEPA). European Commission (09.10).

Castles, S. (2004). Why migration policies fail. Ethnic and Racial Studies, 27(2), 205-227.

Curtin, D., \& Meijers, H. (1997). The principle of open government in Schengen and the European Union: Democratic retrogression? In H. Meijers (Ed.), Democracy, migrants and police in the European Union: The 1996 IGC and beyond (pp. 13-44). Utrecht: Forum.

Dean, M. (2012). Democracy under attack. How the media distort policy and politics. Bristol: Policy Press.

Faist, T. (2008). Migrants as transnational development agents: An inquiry into the newest round of the migration-development nexus. Population, Space and Place, 14, 21-42. doi:10.1002/ psp.471.

Kent, G. (2013). We are sitting with the big people now. Final report on the PSE's pilot community engagement project in Northern Ireland (March 2012-August 2013). http://www.poverty.ac.uk/

Lukes, S., Jones, V., \& San Juan, Y. (2009). The potential of Migrant and Refugee Community Organisations to influence policy. JRF.

Migrant Voice. (2014). Migrants invisible in UK media (16th June). http://migrantvoice.org/

Migration Observatory. (2013). Migration in the news: Portrayals of immigrants, migrants, asylum seekers and refugees in national British newspapers 2010-2012. www.migrationobservatory. ox.ac.uk/sites/files/migobs/Report\%20-\%20migration\%20in\%20the\%20news.pdf. Accessed 5 Dec 2013.

Migreurop. (2012). At the margins of Europe. The externalisation of migration controls. www.migreurop.org/IMG/pdf/Rapport_Migreurop_2011_Version_anglaise_27012012_ pour_derniere_relecture_et_validation_FASTI-SM.pdf. Accessed 13 June 2014.

Papademetriou, D. G., \& Heuser, A. (2009). Public opinion, media coverage, and migration: Developing strategies for immigration and integration reforms. Migration Policy Institute. http://www.migrationpolicy.org/research/public-opinion-media-coverage-and-migrationdeveloping-strategies-immigration-and

Philo, G., Briant, E., \& Donald, P. (2013). Bad news for refugees. London: Pluto Press.

PSE. (2014). PSE poverty and social exclusion website. Part of the poverty and social exclusion in the United Kingdom research project (ESRC reference RES-060-25-0052). www.poverty.ac.uk

Singleton, A. (2009). Moving Europe: EU research on migration and policy needs. European Commission, Luxembourg: Office for Official Publications of the European Communities.

Spigelman, A. (2013). The depiction of Polish migrants in the United Kingdom by the British press after Poland's accession to the European Union. International Journal of Sociology and Social Policy, 33(1/2), 98-113.

Statewatch. (2012). FOI in the EU. Freedom of information in the European Union. http://www. statewatch.org/foi/foi.htm. Accessed 15 Nov 2013.

Statewatch. (2014). Observatories on civil liberties, openness and secrecy in Europe. http://www. statewatch.org/observatories.htm

The Journal.ie (22.06.14). Politicians are not allowed to talk to people seeking asylum in Ireland. http://www.thejournal.ie/direct-provision-politicians-not-allowed-canvas-1463456-May2014/

Triandafyllidou, A. (2009). Greek immigration policy at the turn of the 21st century. Lack of political will or purposeful mismanagement? European Journal of Migration and Law, 11(2), 159-177.

Walters, W. (2010). Migration and security. In J. Peter Burgess (Ed.), The handbook of new security studies (pp. 217-228). London: Routledge. 